\title{
Sosyal Bilgiler Öğretmenlerinin Hoşgörü Eğitimine Bakışı ve Hoşgörü Eğitimine \\ İlişkin Uygulamaları ${ }^{1}$
}

\section{Social Studies Teachers' Perceptions of Tolerance Education and Tolerance}

\section{Education Practices}

\section{Hatice TÜRE}

Anadolu University, Turkey

haticeture@anadolu.edu.tr

\section{Arife Figen ERSOY}

Anadolu University, Turkey

arifee@anadolu.edu.tr

\section{Özet}

$\mathrm{Bu}$ araştırmanın amacı, sosyal bilgiler öğretmenlerinin hoşgörü eğitimine bakışını ve hoşgörü eğitimine ilişkin uygulamalarını anlamaktır. Araştırmaya ölçüt örneklem ile belirlenen 10 sosyal bilgiler öğretmeni katılmıştır. Araştırmanın verileri yarıyapılandırılmış görüşme yoluyla toplanmış ve tematik olarak analiz edilmiştir. Araştırma sonucunda sosyal bilgiler öğretmenlerinin çoğu hoşgörünün eğitimle kazandırılabileceğini, eğitimli insanların daha hoşgörülü olduklarını ve öğretmenin hoşgörülü olması gerektiğini vurgulamışlardır. Sosyal bilgiler öğretmenleri, hoşgörü için değerlerin ve farklı kültürlerin öğretilmesi gerektiğine vurgu yapmışlardır. Sosyal bilgiler öğretmenleri, hoşgörü eğitimi aldıktan sonra öğrencilerin empati becerisine sahip, farkl1lıklara saygı gösteren, özgüvenli, sabırlı, kurallara uyan, nesnel, iletişim becerileri gelişmiş ve geniş bir bakış açısına sahip bireyler olmaları gerektiğini belirtmişlerdir. Sosyal bilgiler öğretmenleri hoşgörü eğitimine yönelik olarak derslerinde daha çok sınıfta gelişen olaylarla ilgili konuştuklarını belirtmişlerdir. Sosyal bilgiler öğretmenleri, ders dışında ise sınıf rehber öğretmeni olarak hoşgörüye değindiklerini, hoşgörüye yönelik kitap kampanyası ve yarışma düzenlediklerini de belirtmişlerdir. Sosyal bilgiler öğretmenleri, Sosyal Bilgiler Öğretim Programı'nda hoşgörüye yeterince yer verilmediğini belirtmişlerdir. Öğretmen, öğrenci ve ailelerin hoşgörü algısını geliştirecek eğitim etkinlikleri düzenlenebilir. Ailelerin ve öğrencilerin hoşgörü algısını belirleyecek nicel ve nitel çalışmalar yapılabilir.

Anahtar Kelimeler: Değer, Hoşgörü, Sosyal Bilgiler, Vatandaşlık

\footnotetext{
${ }^{1}$ Bu makale, "Sosyal Bilgiler Öğretmelerinin Hoşgörü Algısı ve Hoşgörü Eğitimine Bakışı” adlı yüksek lisans tezinden üretilmiştir.

2 Bu makale, 24-26 Nisan 2014 tarihlerinde 1. Avrasya Eğitim Araştırmaları Kongresi'nde sözlü bildiri olarak sunulmuştur.
} 


\begin{abstract}
The purpose of this study is to understand social studies teachers' perceptions of tolerance education and their practices. The participants were 10 social studies teachers who were determined using criterion sampling. The data were gathered through semistructured interviews and analysed thematically. According to the results of the study, most of the teachers emphasized that tolerance could be gained through education, educated people were more tolerant, and teachers should be tolerant. The social studies teachers emphasized that values and diversities should be taught for tolerance. The teachers also pointed out that after receiving tolerance education, the students should have empathy, be respectful for diversities, confident, patient, obey the rules, be objective, have developed communication skills and have a broad perspective. They stated that with regard to tolerance, they mostly talked about events emerging in the classroom during their lessons. Moreover, the teachers, as the guidance teachers, talked about tolerance outside the classroom, and organized book activities and competitions towards tolerance. They indicated that tolerance was not included in the Social Studies curriculum sufficiently. Educational activities which will improve teachers', families' and students' perceptions of tolerance can be arranged. Qualitative and quantitaive researchs can be conducted about families' and students' perceptions of tolerance.
\end{abstract}

Key Words: Values, Tolerance, Social Studies, Citizenship 
Anadolu Journal of Educational Sciences International, January 2015, 5(1)

\section{Giriş}

Küreselleşme, bilgi ve iletişim teknolojilerinin etkisiyle insanlar arası etkileşim artmış ve farklı kültürlere sahip birçok insan birlikte yaşamaya ve çalışmaya başlamıştır. Bu durum, hoşgörünün günümüzde giderek daha çok önem kazanmasına ve bireylerde aranan evrensel değerler arasında yer almasına neden olmuştur. Aynı zamanda hoşgörü, demokratik toplumlarda demokrasinin ve insan haklarının gelişimi için her vatandaşın sahip olması gereken temel değerlerden biridir (Colesante ve Biggs, 1999; Güven ve Akkuş, 2004; Kavcar, 1995; Tezcan, 1995; Weidenfeld, 2002; Yürüşen, 1996; Widmalm, 2005). "Dünyadaki farklı kültürel zenginliği kabul etme, takdir etme ve bu çeşitliliğe saygı duyma" (UNESCO, 1995, s.9) olarak tanımlanan hoşgörü, demokratik toplumlarda aranan temel değerlerdendir. Demokratik yönetimlerin ve demokratik kuralların işlemesi, bir demokrasi kültürüne, bu kültürün de hoşgörü anlayışına dayanması gerekmektedir. Toplumdaki bireylerin farklılıklara ve aykırılıklara hoşgörü ile yaklaşabilmesi, hoşgörünün bir toplumda yaşayan bireyler tarafından benimsenmesi ve içselleştirilmesi ile sağlanabilir (Gözübüyük, 2002).

İnsan hakları ve bireylerin temel özgürlüklerinin tanınmasını sağlayan bir değer olan hoşgörüye ulusal ve uluslararası insan hakları belgelerinde yer verilmiştir. İnsan Hakları Evrensel Bildirgesi'nin (1948) 26. maddesinde, eğitim sürecinin bütün uluslar, ırk veya din toplulukları arasında anlayışı, hoşgörüyü ve dostluğu özendirmesi vurgulanmıştır. 1989 tarihli Birleşmiş Milletler Çocuk Hakları Sözleşmesi'nin 29. maddesinde ise “Çocuğun anlayış, barış, hoşgörü, cinsler arası eşitlik ve tüm insanlar arasında dostluk ruhuyla, özgür bir toplumda yaşamanın sorumluluklarını üstlenecek biçimde hazırlanması" hakkına sahip olduğu belirtilmiştir. Türkiye'de ise 1982 Anayasası'nda da hoşgörüye yer verilmiştir. 1982 Anayasası'nın 10. maddesinde herkesin dil, 1rk, renk, cinsiyet, siyasal düşünce, felsefi inanç, din, mezhep ve 
Anadolu Journal of Educational Sciences International, January 2015, 5(1)

benzeri sebeplerle ayrım gözetilmeksizin kanun önünde eşit olduğu belirtilmiş ve 14 . maddesinde de demokratik düzeni ortadan kaldıracak, temel hak ve özgürlükleri yok edecek, ayrımcılığa yol açacak davranışların hoşgörü ile karşılanamayacağı vurgulanmıştır. Bu belgelerde belirtildiği gibi gelecek nesillerin hoşgörülü bireyler olarak yetiştirilmesinde eğitim sürecine önemli görevler düşmektedir. Bir toplumda kendinden farklı düşündüğü ve farklı inançlara sahip olduğu için, başkalarını hoşgörüyle karşılamayan, onlara karşı fiziksel baskı ve şiddet uygulayan insanların varlığı hoşgörü eğitiminin gereğini ve önemini göstermektedir (Doğanay, 2007).

Sağlıklı bir toplum için, eğitimin önemli bir görevi de öğrenciler arasında arkadaşlık bağlarının güçlenmesini sağlamak, öğrencilerin paylaşmayı ve uzlaşmayı öğrenmelerine yardımcı olmak, öğrencilerin birlikte dostça ve hoşgörü içinde yaşamalarını sağlamaktır (Gündüz, 1995). Bunun için de öğrenciler arasında bir hoşgörü kültürü oluşturmak gerekmektedir. Hoşgörü kültürü oluşturmak için öncelikle hoşgörünün eğitimde bir ilke olarak benimsenmesi ve yeni yetişen bireylerin bu ilke doğrultusunda eğitilmeleri gerekmektedir (Y1lmaz, 2004’ten akt., Tatar, 2009). Hoşgörünün yaşanılarak kazanılacağı ortam, demokrasiyle yönetilen aile, toplum ve okuldur. Çocuklar, demokratik bir ortamda hoşgörüyü bir ürün olarak kazanır ve başkalarıyla iyi ilişkiler kurmada bu ürünü bir araç olarak kullanılır (Başaran, 1995). Hoşgörüsüzlük, öğrenilmiş bir davranış olduğu ve bu davranışın hoşgörü eğitimi yoluyla değiştirilebileceğinden hareket ederek (Şahin, 2011) toplumda hoşgörünün yapılandırılmasında en temel kurumun okul olduğu söylenebilir (UNESCO, 1994).

Hoşgörüsüzlüğü önlemek için, kültürel, sosyal, ekonomik, siyasi ve dini kaynakların tümü ele alınarak sistematik ve akılcı olarak hoşgörü eğitimi gerçekleştirilmelidir. Eğitim politikaları ve programları, farklı etnik, sosyal, kültürel, dini ve dilsel kökene sahip gruplar ve uluslar arasında 
Anadolu Journal of Educational Sciences International, January 2015, 5(1)

dayanışma, anlayış ve hoşgörünün gelişmesine katkı sağlamalıdır ve hoşgörü eğitimi bir zorunluluk olarak görülmelidir (UNESCO, 1995). Hoşgörü eğitimi sayesinde bireyler, fikirlerin serbestçe ifade edilebilmesinin gerekli olduğunu, farklı olmanın da kötü, olumsuz ya da tehlikeli olmadığını öğrenirler (Gürkaynak, 1995). Hoşgörü eğitiminin amaçlarından biri, sosyal adaleti sağlayabilen bir dünya düzeninin oluşturulmasına katkı sağlayacak stratejiler hakkında öğrencilere yardımcı olmaktır (Şahin, 2011). Hoşgörü eğitiminin ilk adımı, bireylere ortak olan temel hak ve özgürlükleri, demokrasiyi öğretmektir. Bir bakıma hoşgörü eğitimi, demokrasi eğitimidir (Weidenfeld, 2002). Ayrıca hoşgörü eğitimi, genç insanların bağımsız yargılama, eleştirel düşünme ve etik olarak akıl yürütme becerilerinin gelişmesine yardımcı olmalıdır (UNESCO, 1995).

Hoşgörü, vatandaşlık eğitiminin de önemli bir öğesidir (Weidenfeld, 2002). Haklarını bilen ve sorumluluklarını yerine getiren bireyler yetiştirmek için vatandaşlık eğitiminde hoşgörüye yer verilmelidir (Colesante ve Biggs, 1999). Hoşgörü eğitiminde, öğrencilere demokrasi, barış, uyuşmazlıkların barışçı yollarla çözülmesi, işbirliği, katılım, iletişsim becerilerinin geliştirlmesinin yanı sıra haklarına sahip çıkabilme ve sorumluluklarını yerine getirebilme, yeterlikleri kazandırılmalıdır (Gürkaynak, 1995). Hoşgörü eğitimi, şiddet ve dışlamalara neden olan hoşgörüsüzlüğü oluşturan kültürel, sosyal, ekonomik, siyasal ve dinsel kaynaklara da yönelmelidir. Ayrıca eğitim programları, dayanışmaya, toplumda etnik, sosyal, kültürel ve dinsel ayrımcılığın yok edilmesine yönelik olmalıdır (Topuz, 1996). Paylaşımcı, eşitlikçi, saygılı, farklılıkları kabul eden ve barışçı gençlerin yetiştirilebilmesi için hoşgörü ile ilgili kavramların çocuklara benimsetilmesi gerekmektedir (Tatar, 2009). Hoşgörünün çocuklar tarafından benimsenmesi için hoşgörünün eğitim, kültürel, yasal ve diğer tüm toplumsal alanlarda yaşanması gerekir (Rice, 2009). Hoşgörü, öğrenci kimliğinin de en önemli unsurlarından biridir. 
Anadolu Journal of Educational Sciences International, January 2015, 5(1)

Bu nedenle öğrenci, yabancı kültürlere karşı açık ve önyargısız olmalıdır (Thompson, 2010). Bu amaçla, okullarda her bir öğrencinin, farklı özelliklere sahip olduğu düşünülerek kapsayıcı bir eğitim gerçekleştirilmeli (Khitruk ve Ulianova, 2012), eğitimde farklı din ve yaşam tarzlarına yer verilmeli, drama gibi farklı yöntemler ile farklı kültürlere ilişkin resimler ve müzikler kullanılmalıdır (Hansen, 2011).

Hoşgörü eğitiminde öğretmenler önemli bir yere sahiptir. Öğretmenin hoşgörü eğitimi konusunda yeterli donanıma sahip olması, okullardaki hoşgörü ve bir arada yaşama kültürünün oluşmasında en önemli etkenlerdendir (Kaymakcan, 2007). Bu bağlamda, hoşgörü eğitimini gerçekleştirecek olan öğretmenlerin hoşgörü eğitimine ilişkin görüşleri ve uygulamalarının bilinmesi önem taşımaktadır. Sosyal bilgiler öğretmenleri, ilkokul ve ortaokulda sosyal bilgiler, T.C. inkılap tarihi ve Atatürkçülük ile vatandaşlık ve demokrasi eğitimi derslerini yürütmektedir. Bu dersler, vatandaşlık eğitiminde dolayısıyla hoşgörü eğitiminde önemli rol oynamaktadır.

Sosyal bilgiler dersi, sosyal ve insanla ilgili olan bilimlerin içerik ve yöntemlerinden yararlanarak, insanın fiziksel ve sosyal çevresiyle etkileşimini zaman boyutu içinde ele alan ve küreselleşen bir dünyada yaşamla ilgili temel demokratik değerlerle donatılmış, vatandaşlar yetiştirmeyi amaçlayan bir çalışma alanıdır (Doğanay, 2002). Çok disiplinli bir doğası olan sosyal bilgiler, insan davranışına odaklanır (Welton ve Mallan, 1999) ve sosyal bilgiler dersinin en temel amaçlarından biri, bireylere demokratik yaşamın gereği olan değerleri benimsetmektir. Hoşgörü, bu değerlerin en önemlilerindendir. Demokrasi ve hoşgörü, birbirinin nedeni ve sonucudur. Öğrenciler demokratik bir ortamda hoşgörüyü bir ürün olarak kazanır ve bu ürünü başkalarıyla iyi ilişkiler kurmada bir araç olarak kullanırlar (Başaran, 1995). Sosyal Bilgiler Öğretim Programı'nda kazandırılması gereken değerler arasında hoşgörüye yer verilmiştir. Ayrıca, bu programda hoşgörü ile yakından ilgili saygı, sevgi, özgürlük, barış, duyarlılık, adil 
Anadolu Journal of Educational Sciences International, January 2015, 5(1)

olma, uzlaşmanın da yer aldığı görülmektedir. Aynı zamanda Sosyal Bilgiler Öğretim Programı'nda doğrudan ve dolaylı olarak hoşgörüyü geliştirecek kazanımlara yer verilmiştir. Sosyal bilgiler öğretmenlerinin ortaokullarda yürüttüğü derslerden biri de T.C. inkılap tarihi ve Atatürkçülük dersidir. Bu ders aracılığıyla, 20. yüzyılın başlarında Türkiye'nin yaşadığı olayların neden ve sonuçlarının çocuklara öğretilmesi, geleceğe yönelik doğru adımlar atma açısından önem taşımaktadır (Palaz, 2010). Bu ders, Kurtuluş Savaşı sonunda kurulmuş olan yeni devletinin ideolojisini topluma benimsetme ve vatandaşlık eğitimine katkı sağlama amacıyla ilköğretim programında yer almaktadır (Yılmaz, 2005). Bu dersin öğretim programında hoşgörü kazandırılacak değerler arasında yer almamasına karşın dolaylı olarak hoşgörüyle ilgili kazanımlara yer verilmiştir. Vatandaşl1k ve demokrasi eğitimi dersi ise, ortaokullarda öğrencilerin vatandaşlık bilgi, beceri ve değerlerini geliştirmeyi amaçlayan bir derstir. Bu dersin öğretim programında hoşgörü kazandırılacak değerler arasında yer alırken doğrudan ve dolaylı olarak hoşgörüyü geliştirmeyi amaçlayan kazanımlara da yer verilmiştir. Bu derslerin öğretim programlarında doğrudan ve dolaylı olarak hoşgörüyle ilişkili kazanımlara Tablo 1'de (Milli Eğitim Bakanlığı [MEB], 2013a; MEB, 2013b; MEB, 2013c; MEB, 2013d) yer verilmiştir.

Tablo 1

Sosyal Bilgiler, T.C. Inkilap Tarihi ve Atatürkçülük ve Vatandaşlık ve Demokrasi Eğitimi Derslerindeki Hoşgörüyle İlgili Kazanımlar

\begin{tabular}{|c|c|c|}
\hline Ders & Sinif & İlgili kazanım \\
\hline \multirow{8}{*}{ 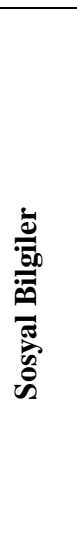 } & 4 & $\begin{array}{l}\text { Bireysel farklılıkları tanır ve kabul eder. } \\
\text { Başkalarının duygu ve düşüncelerini saygı ile karşılar. } \\
\text { Görsel materyallerden yararlanarak çeşitli toplumların günlük yaşamlarına ilişkin çıkarımlarda } \\
\text { bulunur. } \\
\text { Kendisi ile bir başka ülkedeki insanların yaşam şartlarını karşılaştırır. }\end{array}$ \\
\hline & \multirow{5}{*}{5} & Çocuk olarak haklarını fark eder. \\
\hline & & Toplumsal yaşamı düzenleyen yasaların varlığını ve önemini fark eder. \\
\hline & & Ulusal Egemenlik ve bağımsızlık sembollerine değer verir. \\
\hline & & Dünya çocuklarının ortak yönlerini ve ilgi alanlarını fark eder. \\
\hline & & Bir soruna getirilen çözümlerin hak, sorumluluk ve özgürlükler temelinde olması gerektiğini savunur. \\
\hline & & $\begin{array}{l}\text { Demokratik yönetimlerde yaşama hakkı, kişi dokunulmazlığı hakkı, din, vicdan özgürlüğü ile düşünce } \\
\text { özgürlüğüne sahip olunması gerektiğini savunur. }\end{array}$ \\
\hline & 6 & $\begin{array}{l}\text { Türk tarihinde kadının konumu ile ilgili örnekleri, kadın haklarının gelişimi açısından yorumlar. } \\
\text { Doğru bilgi alma hakkı, düşünceyi açıklama özgürlüğü ve kitle iletişim özgürlüğü arasındaki }\end{array}$ \\
\hline
\end{tabular}


bağlantıyı fark eder.

7 Kitle iletişim özgürlüğü ve özel hayatın gizliliği kavramlarını, birbiriyle ilişkileri çerçevesinde yorumlar.

Osmanlı toplumunda hoşgörü ve birlikte yaşama fikrinin önemine dayalı kanıtlar gösterir.

Tarihsel süreçte düşünceyi ifade etme ve bilim özgürlüklerini bilimsel gelişmelerle ilişkilendirir.

\begin{tabular}{|c|c|c|}
\hline 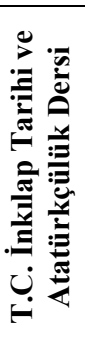 & 8 & $\begin{array}{l}\text { Atatürk'ün kadınlara sağladığı sosyal ve siyasal hakları önemin çeşitli ülkelerindeki kadın haklarıyla } \\
\text { karşılaştırarak eğerlendirir } \\
\text { Millî egemenlik, eşitlik, adalet, demokratik hak kavramlarını Atatürkçü düşünce sistemindeki halkçılık } \\
\text { ilkesi ile ilişkilendirir. } \\
\text { Atatürk'ün ölümü üzerine yayımlanan yazılı ve görsel kanıtlardan hareketle onun kişilik özellikleri ile } \\
\text { fikir ve görüşlerinin evrensel değerine ilişkin çıarımlarda bulunur. } \\
1945 \text { sonrası insan hak ve özgürlükleri ile demokratik anlayışın gelişimine yönelik uygulamalara } \\
\text { örnekler verir. }\end{array}$ \\
\hline 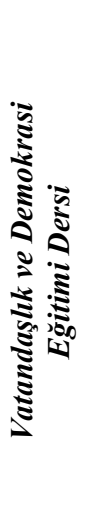 & 8 & $\begin{array}{l}\text { Her bireyin kendine has özelliklerinin olduğunu kabul eder. } \\
\text { İnsanlığın insanî değerlerle korunup geliştirileceğini kabul eder. } \\
\text { İnsanın varlığının ve onurunun korunmasında insan haklarının ve demokrasinin önemini fark eder. } \\
\text { Demokrasinin temel özelliklerini kavrar. } \\
\text { Demokratik bir vatandaş olmanın gereklerini örneklerle açıklar. } \\
\text { Farklı görüş, düşünce, inanç, anlayış ve kültürel değerlerin toplumsal yaşamı zenginleştirdiğini kavrar. } \\
\text { Ayrımcılığın çeşitli biçimlerini sorgulayarak ayrımcılık yapmama konusunda duyarlılık gösterir. } \\
\text { Hak, özgürlük ve sorumluluk arasındaki ilişkiyi fark eder. } \\
\text { İnsan haklarının ve özgürlüklerinin herkes için doğuştan ve vazgeçilmez olduğunu kavrar. } \\
\text { Hak ve özgürlüklerin demokratik bir ortamda gerçekleşebileceğini fark eder. Toplumun birlik ve } \\
\text { beraberliğini sağlayan değerleri koruma ve geliştirme konusunda sorumluluk üstlenir. } \\
\text { Engelli, yaşlı vb. bireylerle empati yaparak onların rahat bir yaşam sürdürebilmeleri için sorumluluk } \\
\text { üstlenir. } \\
\text { Devletin vatandaşlarına karşı görev ve sorumluluklarına örnekler verir. }\end{array}$ \\
\hline
\end{tabular}

Alanyazında, yurt içinde ve dişında ilköğretim öğrencilerinin (Çalışkan ve Sağlam, 2012; Lintner, 2005), üniversite öğrencilerinin (Gürkan, 1995), hoşgörü algısı çalışılmıştır. Ayrıca, öğretmen adaylarının (Stevens ve Charles, 2005; Şahin, 2011), öğretmenlerin (Büyükkaragöz ve Kesici, 1996; Kepenekçi, 2004; Türe ve Ersoy, 2014), ve öğretim elemanlarının (Kıroğlu, Elma, Kesten ve Egüz, 2012) hoşgörü algısına ilişkin çalışmalar yapılmıştır. Ancak yurt içinde sosyal bilgiler öğretmenlerinin hoşgörü eğitimi uygulamalarına ilişkin yapılmış çalışmaya rastlanmamıştır. Toplumların barış ve huzur içinde birarada yaşamasını sağlayan değerlerden biri olan hoşgörünün, eğitiminin nasıl gerçekleştirildiğinin bilinmesi demokratik bireyler yetiştirilmesi için önem taşımaktadır. Bu bağlamda, vatandaşlık eğitimi ve hoşgörü eğitiminde önem taşıyan sosyal bilgiler öğretmenlerinin hoşgörü eğitimine ilişkin görüşleri ve uygulamalarının bilinmesi gerekmektedir. $\mathrm{Bu}$ araştırmada, sosyal bilgiler öğretmenlerinin 
Anadolu Journal of Educational Sciences International, January 2015, 5(1)

hoşgörü eğitimine yönelik görüşleri ve uygulamaları anlaşılmaya çalışılmıştır. Bu araştırma sonuçlarının, sosyal bilgiler öğretmenlerinin hoşgörü eğitimindeki eksikliklerini belirlenmesini ve yaşadıkları sorunların ortaya konmasını sağlayarak sosyal bilgiler eğitimine katkı getireceği düşünülmektedir.

\section{Araştırmanın Amacı}

$\mathrm{Bu}$ araştırmanın amacı, sosyal bilgiler öğretmenlerinin hoşgörü eğitimine ilişkin görüşlerini ve uygulamalarını incelemektir. Bu amaçla şu sorulara yanıt aranmıştır:

1. Sosyal bilgiler öğretmenlerinin hoşgörü eğitimi ile ilgili görüşleri nelerdir?

2. Sosyal bilgiler öğretmenlerinin yürüttükleri derslerin programlarında hoşgörüye yer verilme durumuna ilişkin görüşleri nelerdir?

3. Sosyal bilgiler öğretmenlerinin derslerde hoşgörü eğitimi ile ilgili gerçekleştirdikleri uygulamalar nelerdir?

4. Sosyal bilgiler öğretmenlerinin hoşgörü eğitiminde karşılaştıkları sorunlar ve karşılaştıkları sorunların çözümüne yönelik önerileri nelerdir?

\section{Yöntem}

\section{Araştırma Deseni}

Sosyal bilgiler öğretmenlerinin hoşgörü eğitimine ilişkin görüşleri ile uygulamalarını incelemeyi amaçlayan bu araştırmada nitel araştırma yaklaşımı benimsenmiştir. Nitel araştırma, gözlenemeyen insan eylemlerinin iç nedenlerini ortaya çıkarmayı amaçlamaktadır. Nitel araştırmacılar, insanların kendi dünyalarını ve kendi dünyalarında edindikleri deneyimleri nasıl anlamlandırdıklarıyla ilgilenir. Nitel araştırmacıların ana amacı durum, olgu ve olayları katılımcının bakış açısından anlamaktır (Merriam, 2009). Bu araştırmada sosyal bilgiler öğretmenlerinin hoşgörü deneyimlerine derinlemesine odaklanıldığı için nitel araştırma yaklaşımı benimsenmiştir. 
Anadolu Journal of Educational Sciences International, January 2015, 5(1)

$\mathrm{Bu}$ araştırmada, nitel araştırma desenlerinden biri olan olgubilimden yararlanılmıştır. Farkında olduğumuz ancak derinlemesine ve ayrıntılı bir bilgiye sahip olmadığımız olgulara odaklanan (Yıldırım ve Şimşek, 2011) olgubilimde deneyim önemlidir. Bireyin olayları nasıl anlamlandırdığını anlayabilmek için, onun deneyimlerine bakmak gereklidir. Bu deneyimlere bakılarak olgular hakkında derin bir anlayış geliştirilir. Olgubilim deseninde, "Bireyin olguya ilişkin deneyimleri nelerdir?" ve "Bireyin bu olguya ilişkin deneyimlerini etkileyen ortam ve koşullar nelerdir?" sorularına yanıt aranır (Creswell, 2007). Bu araştırmada sosyal bilgiler öğretmenlerinin hoşgörü eğitimine ilişkin görüşleri ile uygulamaları irdelendiği için olgubilim deseniyle gerçekleştirilmiştir. Böylece, sosyal bilgiler öğretmenlerinin hoşgörü eğitimine ilişkin deneyimleri derinlemesine ortaya çıkarılmıştır.

\section{Katılımcılar}

Nitel araştırmalarda amaçlı örnekleme, zengin bilgiye sahip olduğu düşünülen durumların derinlemesine çalışılmasına olanak tanır (İslamoğlu, 2011). Bu araştırmada katılımcıların belirlenmesinde amaçlı örneklem çeşitlerinden ölçüt örneklemden yararlanılmıştır. Ölçüt örneklemede katılımcılar araştırmacı tarafından önemli olduğu düşünülen ölçütlere göre belirlenir (Yıldırım ve Şimşek, 2011). Bu araştırmada sosyal bilgiler öğretmenlerinin belirlenmesinde iki ölçüt temel alınmıştır. Birinci ölçüt, Sosyal Bilgiler Öğretmenliği Programı'ndan mezun olan öğretmenlerin araştırmaya katılmasıdır. Sosyal bilgiler, T.C. inkılap tarihi ve Atatürkçülük ile vatandaşlık ve demokrasi eğitimi derslerini, Edebiyat Fakültelerinin Tarih ve Coğrafya bölümlerinden mezun olan öğretmenler de yürütmektedir. Tarih ve Coğrafya bölümünde verilen eğitim ile sosyal bilgiler öğretmenliğinde verilen eğitim oldukça farklıdır. Sosyal Bilgiler Öğretmenliği Programı mezunu olan öğretmenler, sosyal bilgiler dersinin içeriğine yönelik alan eğitimi aldıkları için bu araştırmada Sosyal Bilgiler Öğretmenliği 
Anadolu Journal of Educational Sciences International, January 2015, 5(1)

Programı mezunu öğretmenlerin katılımcı olarak seçilme örnekleme ölçütü olarak alınmıştır. Ayrıca öğretmenler, programların uygulayıcısı oldukları için onların deneyimleri de önem taşımaktadır. $\mathrm{Bu}$ nedenle araştırmada, görüşme yapılan öğretmenlerin en az beş yıllık mesleki deneyime sahip olmaları ikinci örnekleme ölçütü olarak benimsenmiştir.

Araştırmaya katılan sosyal bilgiler öğretmenlerinin yedisi kadın ve üçü erkektir. Tümü Sosyal Bilgiler Öğretmenliği Programı'ndan mezun olan öğretmenlerin sadece biri yüksek lisans mezunudur. Katılımcıların biri altı, biri yedi, biri sekiz, biri dokuz, ikisi 10, ikisi 14 ve biri 15 yıllık hizmet süresine sahiptir. Öğretmenlerin ikisi yalnızca sosyal bilgiler dersini, ikisi sosyal bilgiler ve T.C. inkılap tarihi ve Atatürkçülük derslerini, beşi sosyal bilgiler, T.C. inkılap tarihi ve Atatürkçülük ve vatandaşl1k ve demokrasi eğitimi derslerini, biri de sosyal bilgiler ve din kültürü ve ahlak bilgisi derslerini yürütmektedir.

\section{Verilerin Toplanması ve Analizi}

Olgubilim deseninde, başlıca veri toplama aracı görüşmedir (Yıldırım ve Şimşek, 2011). Bu araştırmanın verileri, yarı-yapılandırılmış görüşme ile toplanmıştır. Olgubilim araştırmalarında derinlemesine bilgi edinmek için katılımcılarla birden fazla görüşme gerçekleştirilir (Creswell, 2007). Bu araştırmada, her öğretmenle iki ayrı görüşme gerçekleştirilmiş ve bu görüşmeler için araştırmacı tarafından iki farklı öğretmen görüşme formu geliştirilmiştir. Görüşme soruları, alan yazın ve uzmanların görüşleri dikkate alınarak oluşturulmuştur. Birinci görüşme formu kişisel bilgiler ve görüşme soruları olmak üzere iki bölümden oluşmaktadır. Birinci görüşme formunun görüşme soruları bölümü toplam dokuz sorudan oluşmaktadır. Birinci görüşmelerden önce, görüşme sorularının anlaşılırlığını sağlamak için iki öğretmenle ön görüşme yapılmıştır. Ön görüşmeler sonrasında görüşme sorularının anlaşılır olduğu görülmüş ve görüşme formunda değişiklik yapılmamıştır. İkinci görüşmelerde sorular her bir öğretmene özgü ve birinci 
Anadolu Journal of Educational Sciences International, January 2015, 5(1)

görüşmelerden elde edilen verilerin daha çok açıklanılması istenen konular üzerine yapılandırılmıştır. Birinci görüşmeler Aralık 2012 ve Ocak 2013 tarihlerinde, ikinci görüşmeler Nisan ve Mayıs 2013 tarihlerinde gerçekleştirilmiştir. Görüşmeler, okullarda öğretmenin uygun gördüğü yerlerde gerçekleştirilmiştir. Görüşmelerde ses kayıt cihazı kullanılmıştır.

$\mathrm{Bu}$ araştırmada, veriler tematik analiz tekniği ile analiz edilmiştir. Tematik analiz tekniğinde veriler öncelikle kodlanır sonra temalandırılır (Liamputtong, 2009). Bu araştırmada da, görüşme dökümleri iki ayrı araştırmacı tarafından kodlanmış ve temalar oluşturulmuştur. Araştırmada kodlayıcılar arası güvenirlik araştırmacı ve uzmanın kodları dikkate alınarak Miles ve Huberman’nın (1994) P(Uzlaşma Yüzdesi)=Na(Görüş Birliği) / Na(Görüş Birliği $)+\mathrm{Nd}($ Görüş Ayrılı̆̆ı) x 100 formülü ile hesaplanmış ve $\mathrm{P}=\% 98$ bulunmuştur.

\section{Bulgular}

\section{Sosyal Bilgiler Öğretmenlerine Göre Etkili Bir Hoşgörü Eğitimi}

Sosyal bilgiler öğretmenleri etkili bir hoşgörü eğitiminde, hoşgörü eğitimin içeriği, öğrenci kazanımları, gerçekleştirilebilecek etkinlikler ve hoşgörülü öğretmenin özelliklerine değinmişlerdir (Tablo 2).

Tablo 2

Sosyal Bilgiler Öğretmenlerinin Etkili Bir Hoşgörü Eğitimine Bakışı

\begin{tabular}{ll}
\hline Hoşgörü eğitiminin içeriği & Değerler \\
& Farklılıklar \\
& Empati \\
& Etkili iletişim becerileri \\
& Kurallar \\
& İnsan hakları \\
& Devlet yönetimi \\
\hline Hoşgörü eğitiminde gerçekleştirilebilecek & Tarihi konular \\
etkinlikler & Okul Yöntem \\
& \\
& Okuma \\
& Drama \\
& Gezi \\
& Örnek olay \\
\hline
\end{tabular}




\begin{tabular}{|c|c|}
\hline & $\begin{array}{l}\text { Seminer } \\
\text { Araç gereç } \\
\text { Gazete } \\
\text { İnternet } \\
\text { Sivil toplum örgütleri } \\
\text { Aile }\end{array}$ \\
\hline Hoşgörü eğitiminden beklenen öğrenci kazanımları & $\begin{array}{l}\text { Empati kurabilen } \\
\text { Farklılıklara saygılı } \\
\text { Etkili iletişimkurabilen } \\
\text { Nesnel bakabilen } \\
\text { Şiddet uygulamayan } \\
\text { Geniş bakış açısına sahip } \\
\text { Özgüvenli } \\
\text { Çevresine zarar vermeyen } \\
\text { Kurallara uyan } \\
\end{array}$ \\
\hline $\begin{array}{l}\text { Hoşgörülü öğretmenin sahip olması gereken } \\
\text { özellikler }\end{array}$ & $\begin{array}{l}\text { Eşit davranmalı } \\
\text { Empati becerisine sahip olmalı } \\
\text { Sabırlı davranmalı } \\
\text { Saygılı olmalı } \\
\text { Çok okumalı } \\
\text { Model olmalı } \\
\text { Öğrencilerine sevgi göstermeli } \\
\text { Dürüst olmalı } \\
\text { Demokratik olmalı } \\
\text { Tutarlı davranmalı } \\
\text { Esnek olmalı }\end{array}$ \\
\hline
\end{tabular}

Sosyal bilgiler öğretmenleri hoşgörü eğitiminde en çok değerler ve farklılıkların öğretimini vurgulamışlardır. Ayrıca, öğretmenler, empati, iletişim, kurallar, insan hakları, devlet yönetimi ve tarihi konuların da hoşörü eğitimiyle verilmesi gerektiğini düşünmektedir. Sosyal bilgiler öğretmenleri sevgi, saygı, dayanışma ve yardımlaşma değerlerinin hoşgörü eğitiminde yer alması gerektiğini düşünmektedir. Öğretmenler görüşlerini, "Kişiyi cinsiyetiyle, diniyle, 1rkıyla vesaire değil de insan olduğu için ona bakmamız gerektiğini öğretmeliyiz... Düşüncelerimizin farklılığını, bireysel farklılıklarımızı onları anlatmak lazım”, ve "Karşısındaki insana değer verme... Sevgi, saygı çok önemli. En temeli bunlar bence arkadaşlık yardımlaşma dayanışma.” gibi sözleriyle ifade etmişlerdir.

Sosyal bilgiler öğretmenleri hoşgörü eğitiminin okulda, sivil toplum kuruluşlarında ve ailede gerçekleşebileceğini düşünmektedir. Hoşgörü eğitiminde okulda kitaplar okutulabileceğini, okul ortamında yaşayarak öğretilebileceğini, hoşgörü eğitiminde drama, gezi, örnek olaylardan 
Anadolu Journal of Educational Sciences International, January 2015, 5(1)

yararlanılabileceğini belirtmişlerdir. $\mathrm{Bu}$ konuda öğretmenler görüşlerini, "Kitaplar tavsiye edilebilir bununla ilgili. Eminim faydalı olacaktır.”, “İla birebir onun hayatından örnek olması gerekiyor. Çocuğun onu yaşaması kendi hayatında görmesi gerekiyor... Bence en uygun yöntemin drama ya da başka yollarla canlandırma yoluyla çocukların bunu kendi hayatlarına yansıtmaları." ve "Demokrasinin asıl işlediği yerleri görmek... Bu tür yerlere geziler düzenlenebilir. $\mathrm{Bu}$ tür çalışmalar yapılan kurumlara gidilebilir...”" sözleriyle dile getirmiştir. Öğretmenler, ders materyalleri olarak hoşgörü eğitiminde gazete ve internetin kullanılabileceğini söylemişlerdir. Bazı öğretmenler, sivil toplum örgütleri aracılığıyla hoşgörü eğitiminin gerçekleştirilebileceğini düşünmektedir. Bu öğretmenler düşüncelerini, “İnsan hakları için de birileri gelebilir sivil toplum örgütlerinden, bunlar konuşturulabilir." ve "Daha çok sivil toplum örgütleri bu konuda ön plana çıkartılabilir.” biçiminde ifade etmiştir. Öğretmenler sivil toplum kuruluşlarının insan hakları ihlallerini göstererek hoşgörüyü geliştirebileceğini düşünmektedir.

Sosyal bilgiler öğretmenleri, hoşgörü eğitimi sonrasında öğrencilerin empati kurabileceklerini, farklılıklara saygılı olabileceklerini, etkili iletişim kurabileceklerini, nesnel bakış açısına sahip olabileceklerini, şiddet göstermeyeceklerini, geniş bakış açısına sahip olabileceklerini, özgüvenli, çevreye zarar vermeyen ve kurallara uyan bireyler olabileceklerini söylemişlerdir. Bir öğretmen hoşgörü eğitiminin empatiyi geliştireceğini "Empati yeteneğine sahip olabilmesi karşısındakinin yerine kendini koyabilmesi." sözleriyle dile getirirken farklıklara saygıyı geliştireceğini düşünen öğretmen görüşlerini, "Birbirleriyle dalga geçmemelerini insan olduğu için arkadaşına değer vermesi gerektiğini. Yani kesinlikle farklılıklara saygılı olmalarını bekliyorum." biçiminde açıklamıştır. Bir öğretmen de, "En önemli şey karşındaki kişiyle iletişime geçtiğinde onu önyargıyla değil onu iletişime açık bir şekilde dinlemeyi öğrenmeli.” diyerek öğrencilerin iletişim becerilerinin gelişeceğini belirtmiştir. 
Anadolu Journal of Educational Sciences International, January 2015, 5(1)

Sosyal bilgiler öğretmenleri, öğrencilerin hoşgörülü olabilmesi için öğretmenlerin de hoşgörülü olması gerktiğini belirtmiş ve hoşgörülü öğretmenin sahip olması gereken özellikleri eşit davranmalı, empati becerisine sahip olmalı, sabırlı davranmalı, saygılı olmalı, çok okumalı, model olmalı, nesnel olmalı, öğrencilerine sevgi göstermeli, dürüst olmalı, demokratik olmalı ve tutarlı davranmalı ve esnek olmalı diyerek betimlemişlerdir. Öğretmenler görüşlerini, “Öğrencilerine eşit yaklaşacak.”, “Adaletli olmalı, eşit davranmalı ayrımcılık yapmamalı”, “Önce empati, öğrencisini tanımalı... Neden hangi davranışı yaptığını tamamen demiyorum ama belki bir kısmını sezinleyebilmeli.”, “İnsan haklarına saygılı olmalı.”, “Hoşgörülü öğretmen önyargılı olmamalı.”, “Demokratik olmalı, hukukun üstünlüğüne inanmalı, insan haklarını iyi bilmeli” diyerek ifade etmişlerdir. Öğretmenlerden biri, bazı öğretmenlerin sınıflarında kaynaştırma öğrencisini istemediklerinden yakınmış ve kaynaştırma öğrencilerini kabullenen ve diğer öğrencilerin de kabul etmesini sağlayan öğretmeni hoşgörülü olarak değerlendirmiştir:

\begin{abstract}
Çocuklar genelde toplumsal, kültürel, ekonomik yapıdan bakıldığında aynı tip çocuklar ama aralarda var birkaç tane farklı olan. Tabi kaynaştırma öğrencilerimiz var... Bazı öğretmenler neden kaynaştırma öğrencileri var onlar gitsinler özel eğitim alsınlar RAM’a (Rehberlik Araştırma Merkezi) gitsinler ya da Milli Eğitimin açtığı başka kurum olsun burada hiçbir şey öğrenemiyorlar. Evet hiçbir şey öğrenemiyorlar gerçekten biz onlara çok fazla ulaşamıyoruz ama yine de içimize katmak anlamında önemli bir şey. Bunları yapabilen öğretmen herhalde hoşgörülü öğretmendir.
\end{abstract}

\title{
Sosyal Bilgiler Öğretmenlerine Göre Öğretim Programlarında Hoşgörü
}

Sosyal bilgiler öğretmenlerinin çoğu, sosyal bilgiler dersinde hoşgörü eğitimine yer verilmesi gerektiğini düşünmektedir. Ancak, öğretmenlerin çoğu, sosyal bilgiler eğitiminin doğasına uygun olduğunu düşünürken bir öğretmen sosyal bilgiler dersinin içeriği ile hoşgörünün çeliştiğini düşünmektedir. Hoşgörünün sosyal bilgiler dersinin doğasına uygun olduğunu düşünen öğretmenler görüşlerini, "Bizim dersimiz bu konuda avantajlı... Biz çocuklara günlük hayatla ilgili birçok fikir verebiliyoruz... Hoşgörüsüzlükten bahsedebiliyoruz, önyargısılıktan 
Anadolu Journal of Educational Sciences International, January 2015, 5(1)

bahsedebiliyoruz tüm farklılıklardan bahsedebiliyoruz.” biçiminde belirtmiştir. Sosyal Bilgiler Öğretim Programı'nda kültür, demokrasi ve insan hakları ile tarihi konuların hoşgörüyle ilgili olduğunu söyleyen öğretmenler görüşlerini “Her bölgenin farklı özelliklerini işliyoruz. Yemek kültüründen tutun da kıyafetlerine halk oyunlarına dügünlerde söylenen şarkılara kadar hemen hemen her şeyi biz orada konuşabiliyoruz.”, “Osmanlı devletini kuruluş sürecinde var adalet ve hoşgörü madde olarak geçiyor." ve "Demokrasi nedir? Monarşi nedir? Yönetim biçimlerini anlatırken niye farklı yönetim biçimleri var insanlar neden bunu tercih ediyor. Günümüzde hala kullanılıyor. Bunlar niye kullanılıyor olabilir?.” diyerek açıklamıştır. Hoşgörü eğitiminin sosyal bilgiler dersinin içeriği ile çeliştiğini düşünen öğretmen ise görüşlerini şöyle dile getirmiştir:

Yani içeriği uymuyor. Yani sen padişah menfaatleri için kardeşlerini ailesini katledip bunun üzerine bir sosyal bilgiler dersi kurgularsan bunun adını da ülkenin menfaati koyarsan... adam kendi menfaati için kardeşlerini yok ediyor bütün sülaleyi kılıçtan geçiriyor. Menfaati için kurallar koyuyor... Ülkenin geleceği için kardeşlerini öldürebilirsin diyor var kitapta var. Onun için sosyal bilgiler dersinde hoşgörüden falan bahsedemezsin. Dersin temeli ben orada öğrenciye hoşgörülü ol diyeceğim, öğrenci orada zorbalığı okuyor, kesmeyi asmayı okuyor. Hocam bak burada ne yazıyor der öğrenci. Onun için dersin içeriği mantığı kurgulanışı gelenek ve zorbalık üzerine kurulu.

Sosyal bilgiler öğretmenlerinin çoğu, vatandaşlık ve demokrasi eğitimi ile T.C. inkılap tarihi ve Atatürkçülük derslerinin öğretim programlarında da hoşgörü eğitimine yer verildiğini belirtmiştir. Vatandaşlık ve demokrasi eğitimi dersi programına ilişkin olarak görüşlerini, "Ben kendi derslerimde... Vatandaşlık dersinde eşitliğe doğru toplumumuzdaki hoşgörü gibi konularda bunları işliyoruz anlatıyoruz ve ben başarılı da olduğumuza inanıyorum.”, "Demokrasilerden bahsediyoruz, demokratik bireylerden, farklılıkların zenginliğinden. Bunların da olabilmesi için hoşgörünün olması gerektiğinden, empati kurulması gerektiğinden bahsediyoruz.” diyerek belirtmişlerdir. T.C inkılap tarihi ve Atatürkçülük dersi öğretim programında hoşgörüye yer verildiğini belirten öğretmenler biri ise, Atatürk'ün hoşgörüsüne yer verildiğini aşağıdaki görüşleriyle dile getirmişlerdir: 
Anadolu Journal of Educational Sciences International, January 2015, 5(1)

Atatürk'ün hoşgörüsü inkılap tarihinde. Onları çok anlatıyorum zaten... Yani esir aldığı komutana bile hoşgörülü şekilde davranıp esiri öldürmemiş. Gayet karşısına alıp hoşgörülü bir şekilde sohbet etmişler. Atatürk’ün hoşgörüsüne gerçekten çok hayranım. Yani ne kadar sinirli olursa olsun sinirlerine hakim olan bir insan gerçekten. Asker olmasına rağmen hoşgörülü bir insan. Bu çok önemli... İnsan ve hayvan hatta bitki sevgisi bile çok gerçekçi.

\section{Sosyal Bilgiler Öğretmenlerinin Hoşgörü Eğitimine Yönelik Uygulamaları}

Sosyal bilgiler öğretmenlerinin hoşgörü eğitimine yönelik uygulamaları, öğretim programı kapsamında gerçekleştirdikleri ders içi etkinlikler ile öğretim programı dışında gerçekleştirdikleri ders dışı etkinlikler olarak çeşitlenmektedir (Tablo 3).

Tablo 3

Sosyal Bilgiler Öğretmenlerinin Hoşgörü Ĕ̆itimine Yönelik Uygulamaları

\begin{tabular}{lc}
\hline $\begin{array}{l}\text { Derslerde gerçekleştirdikleri } \\
\text { uygulamalar }\end{array}$ & $\begin{array}{c}\text { Derslerde veriliş biçimi } \\
\text { Ögretim programı kapsamında yer verme } \\
\text { Sosyal Bilgiler }\end{array}$ \\
& Vatandaşlı ve Demokrasi Eğitimi \\
T.C. İnklap Tarihi ve Atatürkçülük \\
Sınıfta gelişen olaylar \\
Model olma \\
Ele alınan konular \\
Farklılıklar \\
Empati becerisini geliştirme \\
Hoşgörünün sınırı \\
Yöntem ve teknikler \\
Drama \\
Örnek olay \\
Tartışma \\
\hline Ders dişında gerçekleştirdikleri \\
uygulamalar & Rehberlik \\
& Kitap kampanyası \\
\hline
\end{tabular}

Sosyal bilgiler öğretmenleri, ders içinde eğitim programı kapsamında, sınıfta gelişen olaylar ve model olarak hoşgörü eğitimine yer verdiklerini belirtmişlerdir. Sosyal bilgiler öğretmenleri derslerinde farklılıklara saygıya, empatiye, hoşgörünün sınırına değindiklerini ve drama, örnek olay ve tartışma yöntemini kullandıklarını belirtmişlerdir. Sosyal bilgiler öğretmenlerinin bazıları, sosyal bilgiler dersinde daha çok tarihi, hak ve sorumulukları ve yönetim biçimilerini hoşgörü ile ilişkilendirdiklerini vurgulamışlardır. 
Anadolu Journal of Educational Sciences International, January 2015, 5(1)

Öğretmenler, "Haklarım sorumluluklarım gibi kavramlar işte aile değerleri, gelenekler, görenekler... Bu tür şeyleri konuştuğumuzda hoşgörüyü söyleyebiliyoruz. Her bölgede farklı yemek kültürü var... bu tür konuşmalar yapıyoruz." ve "Osmanlının havraları, sinagogları, kiliseleri kapattırmamasi; Ayasofya'ya girip Fatih Sultan Mehmet'in ben dininizi yasaklamıyorum eskisi gibi davranabilirsiniz gibi diyalogları okuyorum. Osmanlının ayakta durmasının temellerinden biri diye çok duruyorum." diyerek sosyal bilgiler dersinde hangi konularda hoşgörüye nasıl yer verdiğini belirtmiştir. Vatandaşlık ve demokrasi eğitimi dersinde hoşgörüye değindiklerini belirten öğretmenler ise görüşlerini, "Vatandaşlık dersinde eşitliğe doğru toplumumuzdaki hoşgörü gibi konularda bunları işliyoruz anlatıyoruz" ve "Vatandaşlık dersimiz de. Yani konular çok fazla var. Ayrımcılık yapılmaması, farkında olunuşluk, bireysel farklılıklarımız falan var. Bunlarla ilgili hep konuştuk tartıştık. Örnekler verdik.” diyerek belirtmişlerdir. Bir öğretmen ise T.C. inkılap tarihi ve Atatürkçülük dersinde Atatürk’ün hayatından bahsederken, onun hoşgörüsü üzerinde de durduğunu, “Atatürk’ün hayatıyla ilgili şeylerde onun hoşgörülü olması kavramını işliyoruz.” biçiminde ifade etmiştir. Snıf içinde gelişen olayları hoşgörü ile ilişkilendirdiklerini ve öğrencilerle konuştuklarını ve fursat eğitimi yaptıklarını dile getiren öğretmenlerden biri görüşlerini şöyle ifade etmiştir: "Öğrenciler konuşuyorlar tartışma yapıyorduk. Bir tanesi konuşurken diğerleri hiç biri dinlemedi bundan önce de saygıdan bahsetmiştik. Sonra dersi durdurdum. Az önce bahsetmiştik herkese saygılı olmalıyız demiştik dedim evet dediler.”

Sosyal bilgiler öğretmenleri ders dışında Rehberlik çalışmalarında, kitap kampanyası ve yarışma gibi etkinliklerde hoşgörüye yer verdiklerini belirtmiştir. Bazı öğretmenler Milli Eğitim Bakanlığı tarafından sınıf rehber öğretmenlerinin uygulaması için gönderilen programda da hoşgörünün yer aldığını ve rehberlik derslerinde hoşgörü, sevgi ve saygı üzerine etkinlikler 
Anadolu Journal of Educational Sciences International, January 2015, 5(1)

gerçekleştirdiklerini "Milli Eğitim geçenlerde öyle bir program yayınladı biz bir ay önce sınıf öğretmenleri rehberlik dersinde haftada bir saat sevgi, saygı ve hoşgörü üzerine bir aylık bir müfredat hazırladık dört haftalık. O dört haftalık süreçte bu konuları işledik. Panolara bununla ilgili yazılar yazdık. Hatta tahmin ediyorsam her sınıfın kapısında bununla ilgili söz vardı." diyerek açıklamışlardır. Bir öğretmen hoşgörü eğitimine ilişkin olarak ders dışı etkinlikler kapsamında sosyo-ekonomik düzeyi düşük öğrencilerin gittiği bir okula kitap yardımı kampanyası düzenlediklerini, başka bir öğretmen ise, yarışmalar düzenlediklerini ve bu yarışmalarda büyük öğrencilerin küçük öğrencilere karşı hoşgörülü olduğunu belirtmiştir. Öğretmenlerden biri özellikle daha büyük yaştaki öğrencilerin küçük öğrencilere daha sabırlı ve hoşgörülü davrandıklarını dile getirmiştir.

\section{Sosyal Bilgiler Öğretmenlerinin Hoşgörü Eğitiminde Karşılaştıkları Sorunlar ve Sorunların Çözümüne Yönelik Önerileri}

Sosyal bilgiler öğretmenleri hoşgörü eğitiminde öğrenciden aileden, eğitim sisteminden ve öğretmenden kaynaklanan sorunlar yaşadıklarını ifade etmişlerdir (Tablo 4). Sosyal bilgiler öğretmenleri, öğrencilerin ben merkezci davranışlarının, şiddet eğilimli davranışlarının, önyargı, dışlama ve farklılıklara karşı saygısızlık davranışlarının hoşgörülü olmalarını engellediğini düşünmektedir. Öğretmenler görüşlerini, "Bencillik varsa hoşgörülü davranamıyor.”, “Mesela sınıflarda bile öğrenciler arasında şiddet oluyor. Çocuk anlaşarak çözemediği şeyi şiddetle çözmeye çalışıyor... Özellikle ergenlik çağında anlatamıyor arkadaşına ve vuruyor”, ve “Öğrenci direk önyargıyla bakıyor.” diyerek açıklamıştır.

Sosyal bilgiler öğretmenleri, ailenin eğitim seviyesinin düşük olmasının, ailelerin ayrımcı davranışlar sergilemesinin, ailelerin çocuklarına söz hakkı vermeden yetiştirmesinin, ailelerin çocuklarına baskı yapmasının ve ailelerin çocuklarını aşırı korumacı yetiştirmesinin çocuklarının 
hoşgörülü olmasını engellediğini düşünmektedir. Bir öğretmen bazı öğrencilerin diğer öğrencileri küçümsediğini ve ezmeye çalıştığını "Kendini çok üstün gören çocuklar var ve bu yüzden diğerlerini ezmeye çalışıyor.” sözleriyle belirtmiştir. Bir öğretmen bazı öğrencilerin ailelerinin cinsiyet ve ekonomik gelir konusunda ayrımcılık yaptıklarını ve bu durumun öğrencilere yansıdığını "Söylediğimiz halde hala ben kız erkek birlikte oturturken veli gelip de benim çocuğumu filanca arkadaşımla oturtur musunuz erkekle oturuyormuş dediğine göre erkek kız diye o şekilde ayrım yaptıklarına göre ya da o fakir o zengin o pis o kokuyor dediklerine göre onlar daha acımasız daha net söylüyorlar duygularını." sözleriyle belirtmiştir. Bir öğretmen de evdeki otorite yapısının öğrencilerin görüşlerinin evde hoşgörü ile karşılanmasını engellediğini "Bir kere evde bir otorite vardır anne baba. Son sözü onlar söyler... Çok da fazla dinlemezler, dinleyen çok az aile vardır..." diyerek belirtmişlerdir.

Tablo 4

Sosyal Bilgiler Öğretmenlerinin Hoşgörü Ĕ̆itiminde Karşılaştıkları Sorunlar

\begin{tabular}{ll}
\hline Öğrenciden kaynaklanan sorunlar & Ben merkezci davranışlar \\
& Şiddete eğilimli davranışlar \\
& Kendi grupları dişındaki öğrencileri dışlama \\
& Önyargılı davranışlar \\
& Farklılıklara karşı anlayışsızlık \\
\hline Aileden kaynaklanan sorunlar & Ailelerin eğitim seviyesinin düşük olması \\
& Ailelerin ayrımcı davranışlar sergilemesi \\
& Ailelerin çocuklarına söz hakkı vermeden yetiştirmesi \\
& Ailelerin çocuklarına baskı yapması \\
\hline Eğitim sisteminden kaynaklanan & Ailelerin çocuklarını aşırı korumacı yetiştirmesi \\
sorunlar & Öğretim programlarının yoğunluğu \\
& Resmi izin/bürokratik işlemler \\
\hline Ö̆ğrik & Ekonomik sorunlar \\
\hline
\end{tabular}

Öğretmenlerin davranışları

Sosyal bilgiler öğretmenleri, öğretim programlarının yoğun olmasını, resmi izin/bürokratik işlemlerinin ve ekonomik sorunların hoşgörü eğitiminde sorun oluşturduğunu düşünmektedir. Öğretmenler ders saatlerinin az olması nedeniyle bazı konulara yeterli değinemediklerini ve 
Anadolu Journal of Educational Sciences International, January 2015, 5(1)

hoşgörüyü geliştirmede yetersiz kaldığını, “Altıncı sınıfa geçtikten sonra bu çok azalıyor hoşgörü eğitimi. Daha ağır konular geliyor ve çocukların artık bunlara ayıracak zamanı da olmuyor... Şu an biraz daha zamanım olsaydı belki tiyatro öğretmeniyle çalışabilirdim.” diyerek belirtirken bazı öğretmenlerde bürokratik işlemler nedeniyle yapmak istedikleri etkinlikleri yapamadıklarını, "Beşinci sınıflar biz çok etkilendik bir kampanya başlatmak istiyoruz kitap kampanyası başlatmak istiyoruz dediler. Hatta başlattılar. İlla ki Van olsun diyorlar. Herhalde depremden dolayı diyorlar... Mesela böyle bir kampanya yapmak çok güzel bir şey ama bu kampanyayı yapmak için her yerden izin almak lazım.” biçiminde ifade etmiştir. Bir öğretmende yaşadığı ekonomik sorunu şöyle dile getirmiştir:

Bir sınıfta dedi ki biz huzur evini, çocuk esirgeme kurumunu oraları ziyaret etmek istiyoruz. Demek ki bir bilinç var kendi içlerinden gelerek bu istekleri talep ediyorlar ama maalesef işte bunlar yaşayarak öğrenme sınıf içinde değil de yaşayarak öğrenme. Ama bunun için dedim ki çocuklar biz şimdi bir çocuk esirgeme kurumuna gitmeye kalksak bir kere ulaşımı nasıl sağlayacağız? Bir kere birilerinin bize destek vermesi lazım. Eğitimimizde bu eksiklikler çok fazla var. Yani diyor ki müfredat müze gez oraya git buraya gel diyor ama bunu nasıl sağlayacağımızı söylemiyor. E çocuklardan da topla et bul zor..

Bazı öğretmenler, hoşgörü eğitimi konusunda öğretmenlerinde dikkatli olmadıklarını ve hoşgörülü olmayan davranışlarla öğrencilere olumsuz örnek olduklarını dile getirmiştir. Bir öğretmen zeka geriliği olan öğrencisinin olduğunu, bu öğrencisinin arkadaşları tarafindan dışlandığını ve öğretmen arkadaşlarının da bu öğrenciye hoşgörüsüz yaklaştığını söylemiştir. Bir öğretmen bu konudaki görüşünü "Bazı öğretmenler sınıfta şey demeye başlamış konuşanları .......'ın yanına oturtacağım diyormuş. Arkadaşım söylemiş bunu dedim.... var mıydı bunu söylerken dedim. Evet ne yapayım valla dayanamadım söyledim dedi." sözleriyle ifade etmişstir.

Sosyal bilgiler öğretmenlerin, hoşgörünün geliştirilebilmesi için eğitim sürecine, aileye, öğretmene ve yazılı ve görsel basına yönelik öneriler sunmuşlardır (Tablo 5). Sosyal bilgiler 
öğretmenleri eğitim sürecine yönelik olarak ailelere, öğretmenlere ve öğrencilere seminerler verilmesini, ders kitaplarının ve programlarının geliştirilmesini önermişlerdir. Ayrıca, sosyal bilgiler öğretmenleri öğretmenlerin model olmasını, demokratik davranmalarını ve derslerinde hoşgörü eğitimine yer vermelerini önermişlerdir. Bir öğretmen halkevlerinden hoşgörü eğitimi amacıyla yararlanılabileceğini şöyle açıklamıştır:

Halk evleri bunun için kullanılabilir. Demokrasi eğitimi olsun ya da bunun uygulamalarının yapıldığı farklı yerler bulunup buralara ev hanımları yönlendirilebilir... Zaten ailede bir birey değiştiği zaman o diğer bireylere de aşılayacaktır... Özellikle anne bu konuda çok daha etkin olur... Anne çocuğunu etkiler çocuk okulda arkadaşlarını etkiler. Bu zincirleme devam eder.

Tablo 5

Sosyal Bilgiler Öğretmenlerinin Hoşgörüyü ve Hoşgörü Ĕgitimini Geliştirmeye Yönelik Önerileri

\begin{tabular}{ll}
\hline Eğitim sürecine yönelik öneriler & Seminerle bilgi verilmeli \\
& Ders kitaplarına hoşgörü eklenmeli \\
Küçük yaşlarda başlamalı & Programlara hoşgörü eklenmeli \\
& Hoşgörüye yönelik ayrı bir ders olmalı \\
& Farklılıklara saygı yerleştirilmeli \\
& Tüm derslerde yer verilmeli \\
& Demokrasi geliştirilmeli \\
& İnsan hakları eğitimi verilmeli \\
& Nesnellik sağlanmalı \\
& Empati geliştirilmeli \\
& Kitap okuması sağlanmalı \\
& Sinıf dışı etkinlikler düzenlenmeli \\
\hline Öğretmene yönelik öneriler & Model olmalı \\
& Demokratik davranmalı \\
& Derslerinde hoşgörüye yer vermeli \\
\hline Aileye yönelik öneriler & Çocuğa model olmalı \\
& Çocukların yaş özelliklerine göre televizyon \\
& izletilmeli \\
Çocuğa söz hakkı verilmeli \\
\hline Yazılı ve görsel basına yönelik öneriler & Hoşgörüye yönelik kamu spotları oluşturulmalı \\
& Hoşgörüye yönelik filmler yapılmalı \\
\hline
\end{tabular}

Bazı öğretmenler, "Kitaplarımızda hoşgörüye yönelik etkinlikler olabilir.” ve "Kitaplara bununla ilgili örnekler, görsel resimler konulabilir.” diyerek ders kitaplarına konuya ilşkin etkinlikler eklenebileceğini dile getirmişlerdir. Öğretmenler ailelerin çocuklarına model olmasını, çocuklara olumsuz örnek olacak televizyon programlarının izletilmemesini ve çocuklarına hoşgörülü 
Anadolu Journal of Educational Sciences International, January 2015, 5(1)

davranılmasını önermiştir. Öğretmenler aileye yönelik önerilerini, "Bir de ailenin içinde önyargıyı uzaklaştırmak lazım. Mesela ailede oluyor yeni biri apartmana taşındığı zaman ya da çevresine geldiği zaman insanlar hemen ona ters bakar... Mesela giyimi senden farklı olduğu zaman beğenmiyorlar birtakım önyargılı konuşmalar oluyor." ve "Mesela ailede bir karar alınacağı zaman çocuğun katılımı sağlanacak... Çocuğun fikirleri alınacak çocuk kendini değerli hissedecek. Çocuk paylaşımcı bir birey olarak yetişecek öncelikle dinlemeyi öğrenecek." biçiminde dile getirmişlerdir. Ayrıca, öğretmenler, "Televizyonda kamu spotu şeklinde bu konuya örnekler verilebilir.” sözleriyle kamu spotlarının hoşgörüye yönelik olarak kullanılabileceğini ve "Konuyla ilgili filmler izlettirilebilir öğrencilere.” diyerek hoşgörüyle ilgili filmler yapılabileceğini ifade etmiştir.

\section{Sonuç, Tartışma ve Öneriler}

Araştırma sonucunda araştırmaya katılan sosyal bilgiler öğretmenlerinin, hoşgörü eğitiminin gerekli ve önemli olduğunu düşündükleri ortaya çıkmıştır. Alanyazında, öğretmenlerin bu görüşüne benzer araştırma sonuçları bulunmaktadır (Karaman-Kepenekçi ve Aybay, 2009; Şahin 2011). Ayrıca, alanyazında eğitimin hoşgörüyü olumlu etkilediği ve eğitimin hoşgörü düzeyini belirleyen ana etmen olduğu vurgulanmaktadır (Colesante ve Biggs, 1999; UNESCO, 1994; Widmalm, 2005).

Araştırmaya katılan sosyal bilgiler öğretmenlerinin çoğu, çocuklara hoşgörülü olmaları için din, cinsiyet, düşünce, yaşam tarzı ve sosyo-ekonomik düzey gibi farklılıkları ve empatiyi öğretmenin önemli olduğunu belirtmişlerdir. Alanyazında da hoşgörü eğitiminde, farklı dini inanç ve yaşam tarzlarına sahip insanların olduğunun öğretilmesi (Hansen 2011) ve empati becerisine yer verilmesi (Khitruk ve Ulianova, 2012) önerilmektedir. Öğretmenlerin hoşgörü 
Anadolu Journal of Educational Sciences International, January 2015, 5(1)

eğitimde belirttikleri öğrenci kazanımları alanyazındaki hoşgörü eğitimi sonrasında kazandırılacak beceri ve değerlerle örtüşmektedir.

Araştırma sonucunda, katılımcı öğretmenlerin hoşgörü eğitimi daha çok ders programları kapsamında gerçekleştirdikleri öğretim etkinliklerinden oluşmaktadır. Öğretmenlerden sadece bir kaçı sınıf rehber öğretmeni olarak derslerinde hoşgörü hakkında konuşmalar yaptığını belirtmiştir. Oysa, hoşgörü eğitiminde ders içi olduğu kadar ders dışında program dışı geliştirilen etkinlikler ve örtük programda önem kazanmaktadır. Bu sonuç, öğretmenlerin hoşgörü eğitimine bakışının daha çok ders içi öğretim programıyla sınırlı olduğunu göstermesi açısından önemlidir. Öğretmenlerin demokrasi eğitimi ve hoşgörü eğitimine ilşkin bakış açısı ve algısını geliştirecek eğitim çalışmalarının gereğini ortaya koymaktadır. Nitekim, öğretmenler, görüşmede, sadece öğrencilere yönelik değil, öğretmenlere yönelik de hoşgörü eğitimi gerçekleştirilmesinin işlevsel olacağını vurgulamışlardır.

Araştırmaya katılan öğretmenler, öğretim programlarında ve ders kitaplarında hoşgörü eğitimini yetersiz bulmuş ve daha çok yer verilmesini önermişlerdir. Alanyazında öğretim programlarında hoşgörüye yer verilmesi gerekliliği vurgulanmaktadır (Hansen, 2011; Weidenfeld, 2002). Katılımcı öğretmenlerin hoşgörü eğitiminde vurguladığı diğer bir sorun, ailenin sosyo-ekonomik düzeyidir. Katılımcı öğretmenlere göre, ailelerin çocuklarını aşırı korumacı yetiştirmeleri, farklı bireylere karşı ayrımcılık yapmaları ve çocuklarına söz hakkı tanımamaları hoşgörülü birey yetiştirilmesini olumsuz etkilemektedir. $\mathrm{Bu}$ sorunun çözümüne yönelik öğretmenler aileye yönelik hoşgörü eğitimi düzenlenmesinin etkili olabileceğini belirtmişlerdir.

Araştırmaya katılan sosyal bilgiler öğretmenlerinin tamamı, hoşgörü eğitiminde öğrencilerden kaynaklı sorunlar yaşadıklarını düşünmektedirler. Bazı öğrencilerin, ben merkezli davranışları, önyargılı davranışları, şiddet eğilimli olmaları ve kaynaştırma öğrencilerine karşı anlayışsız 
Anadolu Journal of Educational Sciences International, January 2015, 5(1)

davranmaları hoşgörüyü ve hoşgörü eğitimini olumsuz yönde etkilediği ortaya çıkmıştır. Araştırmada, katılımcı sosyal bilgiler öğretmenlerinin bazıları, sınıf düzeyi yüksek olan öğrencilerin diğerlerine göre daha hoşgörüsüz tutumlar sergilediğini düşünmektedir. Araştırmanın bu sonucu, Çalışkan ve Sağlam (2012) tarafından gerçekleştirilen çalışmanın, sınıf düzeyi yükseldikçe hoşgörü eğilimlerinin azaldığı sonucuyla benzerlik göstermektedir. Bu sonuç öğrencilerin daha büyük yaşlarda çevresinden sosyal öğrenme ile hoşgörüye ilişkin olumsuz tutumlar edindiği biçiminde yorumlanabilir. Araştırmaya katılan sosyal bilgiler öğretmenlerinin dile getirdiği bir diğer sorun yazılı ve görsel basınla ilgilidir. Katılımcı öğretmenlerin bazıları, kamu spotlarının etkili olduğunu vurgulayıp, yazılı ve görsel basının hoşgörüyü geliştirmeye yönelik olarak kullanabileceğini belirtmişlerdir. Araştırmanın bu sonucuna benzer olarak Hansen (2011) tarafından da, yazılı ve görsel basının hoşgörü geliştirmede etkili olabileceği vurgulanmıştır.

Sonuç olarak, katılımcı öğretmenlerin hoşgörü eğitiminde daha çok farklılıklara saygı ve empatiyi temel alan, ders içinde program kapsamında ilgili konuları ilişkilendirerek drama, örnek olay ve gezi gibi yöntemler kullanarak öğretim temelli uygulamalar gerçekleştirdikleri ve öğretim programı dışında sınıf dışı yeterli uygulama yapmadıkları belirlenmiştir. Ayrıca katılımcı öğretmenlerin hoşgörü eğitimi kapsamında, öğrencilerden, eğitim sisteminden ve aileden kaynaklanan bir dizi sorun yaşadıkları ortaya çıkmıştır. Araştırmadan elde edilen sonuçlar doğrultusunda şu öneriler getirilebilir:

- Öğretmenler, öğrencilerinin aileleriyle birlikte hareket edebilir ve öğrencilerin ben merkezli tutumlarını ortadan kaldırmaya yönelik çalışmalar yapılabilir.

- Öğretmenler, sadece sınıf içinde değil sınıf dışında da hoşgörüye yönelik etkinlikler düzenleyebilir.

- Öğretmenler öğrencilerine eşit davranmalı ve demokratik bir sınıf iklimi oluşturmalılar. 
Anadolu Journal of Educational Sciences International, January 2015, 5(1)

- Öğretmenlere yönelik olarak seminer döneminde hoşgörü eğitimine yönelik hizmet içi eğitim gerçekleştirilebilir.

- Öğretmen, öğrenci ve ailelerin hoşgörü algısını geliştirecek eğitim etkinlikleri düzenlenebilir.

- Öğretmenlerin hoşgörü eğitimi uygulamalarını betimlemek için gözleme dayalı nitel çalışmalar yapılabilir.

- Sosyal bilgiler, vatandaşlık ve demokrasi eğitimi ve T.C. inkılap tarihi ve Atatürkçülük derslerinde hoşgörü eğitimine yönelik programlar geliştirilip deneysel çalışmalar yapılıp etkililiği sınanabilir.

- Öğrencilerin hoşgörü algısını ortaya çıkarmaya yönelik nitel ve nicel çalışmalar gerçekleştirilebilir.

\section{Kaynakça}

Başaran, İ. E. (1995). Hoşgörü ve eğitim. İ. Pehlivan (Yay. Haz.). Hoşgörü ve eğitim toplantısı içinde (ss. 47-56). Ankara: UNESCO Türkiye Milli Komisyonu ve Ankara Üniversitesi Eğitim Bilimleri Fakültesi Ortak Yayın No: 2.

Büyükkaragöz, S., ve Kesici, Ş. (1996). Öğretmenlerin hoşgörü ve demokratik tutumları. Eğitim Yönetimi, 3, 353-365.

Creswell, J. W. (2007). Qualitative inquiry \& research design choosing among five approaches. London: Sage.

Colesante, R. J., \& Biggs, D. A. (1999). Teaching about tolerance with stories and arguments. Journal of Moral Education, 28(2), 185-199.

Çalışkan, H., ve Sağlam, H. İ. (2012). Hoşgörü eğilim ölçeğinin geliştirilmesi ve ilköğretim öğrencilerinin hoşgörü eğilimlerinin çeşitli değişkenler açısından incelenmesi. Kuram ve Uygulamada Ĕ̆itim Bilimleri, [Değerler Eğitimi Ek Özel Sayısı], 12(2), 1431-1446. 
Anadolu Journal of Educational Sciences International, January 2015, 5(1)

Doğanay, A. (2007). Değerler eğitimi. C. Öztürk (Ed.). Hayat bilgisi ve sosyal bilgiler öğretimi içinde (ss. 256-284). Ankara: Pegem A Yayıncılık.

Doğanay, A. (2002). Sosyal bilgiler öğretimi. C. Öztürk ve D. Dilek (Edt.). Hayat bilgisi ve sosyal bilgiler ögretimi içinde (ss.15-46). Ankara: Pegem A Yayıncılık.

Gözübüyük, M. (2002). Türkiye’de demokrasi ve hoşgörü kültür ve eğitiminin yaygınlaşmasında sivil toplum kuruluşlarının yeri ve önemi. Yayımlanmamış Yüksek Lisans Tezi, Ankara Üniversitesi, Eğitim Bilimleri Enstitüsü, Ankara. http://tez2.yok.gov.tr/ adresinden edinilmiştir.

Gündüz, M. (1995). Açılış konuşması. İ. Pehlivan (Yay. Haz.). Hoşgörü ve eğitim toplantısı içinde (ss. 12-16). Ankara: UNESCO Türkiye Milli Komisyonu ve Ankara Üniversitesi Eğitim Bilimleri Fakültesi Ortak Yayın No: 2.

Gürkan, T. (1995). Üniversite öğrencilerinin hoşgörü kavramına bakışı. Hoşgörü ve $\quad$ Eğitim Toplantısı, 12-16, Ankara.

Gürkaynak, İ. (1995). Farklı boyutları ile hoşgörü. İ. Pehlivan (Yay. Haz.). Hoşgörü ve eğitim toplantısı içinde (ss. 34-38). Ankara: UNESCO Türkiye Milli Komisyonu ve Ankara Üniversitesi Eğitim Bilimleri Fakültesi Ortak Yayın No: 2

Güven, A. ve Akkuş, Z. (2004). Demokratik değer kazanımında okulların rolü. Kazım Karabekir Eğitim Fakültesi Dergisi, 9, 217-224.

Hansen, O. H. B. (2011). Teaching tolerance in public education: organizing the exposure to religious and life-stance diversity. Religion \& Education, 38,111-127.

İslamoğlu, A. H. (2011). Sosyal bilimlerde araştırma yöntemleri. (2. bs.). İstanbul: Beta Yayıncılık 
Anadolu Journal of Educational Sciences International, January 2015, 5(1)

Karaman-Kepenekçi, Y., ve Aypay, A. (2009). Teachers' perceptions of tolerance in teacheradministrator relationships in Turkey. International Journal of Leadership in Education: Theory and Practice, 12(1), 51-71.

Kavcar, C. (1995). Açılış konuşması. İ. Pehlivan (Yay. Haz.). Hoşgörü ve eğitim toplantısı içinde (ss. 1-4). Ankara: UNESCO Türkiye Milli Komisyonu ve Ankara Üniversitesi Eğitim Bilimleri Fakültesi Ortak Yayın No: 2.

Kaymakcan, R. (2007). Bir değer olarak hoşgörü ve eğitimi. Değerler Ĕ̆itimi Merkezi Dergisi, 2(6), 114-119.

Kepenekçi, K. Y. (2004). Sınıf öğretmenlerine göre hoşgörü. Kuram ve Uygulamada Eğitim Yönetimi, 38, 250-265.

Khitruk, V. V., \& Ulianova, O. A. (2012). Inclusive tolerance as a basis of professional competence of prospective teachers. Problems of Education in The 21st Century, 43, 21-32.

Kıroğlu, K., Elma, C., Kesten, A. ve Egüz, Ş. (2012). Üniversitede demokratik bir değer olarak hoşgörü. Journal of Social Studies Education Research, 3(2), 86-104.

Liamputtong, P. (2009). Qualitative data analysis: conceptual and practical considerations. Health Promotion Journal of Australia, 20(2), 133-139.

Lintner, T. (2005). A world of difference: teaching tolerance through photographs in elementary school. The Social Studies, January/February, 34-37.

Merriam, S. B. (2009). Qualitative research: a guide to desing and implementation. San Francisco: Jossey-Bass Publishers.

Miles, M. B., \& Huberman, M. A. (1994). An expanded sourcebook qualitative data analysis. London: Sage. 
Anadolu Journal of Educational Sciences International, January 2015, 5(1)

Milli Eğitim Bakanlığı. (2013a). Sosyal bilgiler (4-5. sınıflar) öğretim programı ve kılavuzu. Milli Eğitim Bakanlı̆̆ $\quad$ Talim ve Terbiye Kurulu Başkanlığı http://ttkb.meb.gov.tr/program2.aspx web sitesinden 09.04.2013 tarihinde alınmıştır.

Milli Eğitim Bakanlığı. (2013b). Sosyal bilgiler (6-7. sınıflar) öğretim programı ve kılavuzu. Milli Eğitim Bakanlığı Talim ve Terbiye Kurulu Başkanlığı http://ttkb.meb.gov.tr/program2.aspx web sitesinden 09.04.2013 tarihinde alınmıştır.

Milli Eğitim Bakanlığı. (2013c). Türkiye cumhuriyeti inkılap tarihi ve Atatürkçülük öğretim programı ve kılavuzu. Milli Eğitim Bakanlığı Talim ve Terbiye Kurulu Başkanlığı http://ttkb.meb.gov.tr/program2.aspx web sitesinden 09.04.2013 tarihinde alınmıştır.

Milli Eğitim Bakanlı̆̆ı, (2013d). Vatandaşlık ve demokrasi ĕgitimi öğretim programı ve kılavuzu. Milli Eğitim Bakanlığı Talim ve $\quad$ Terbiye Kurulu Başkanlığ http://ttkb.meb.gov.tr/program2.aspx web sitesinden 09.04.2013 tarihinde alınmıştır.

Palaz, T. (2010). İlkögretim 8. sınıf Türkiye cumhuriyeti inkılâp tarihi ve Atatürkçülük dersinde karikatür kullanmanın öğrenci başarısına ve derse karşı tutumuna etkisi. Yayımlanmamış yüksek lisans tezi. Gazi Üniversitesi, Eğitim Bilimleri Enstitüsü, Ankara.

Rice, S. (2009). Education for toleration in an era of zero tolerance school policies: A dewey an analysis. Educational Studies, 45, 556-571.

Stevens, R. ve Charles, J. (2005). Preparing Teachers to Teach Tolerance. Multicultural Perspectives, 7(1), 17-25.

Şahin, Ç. (2011). Perceptions of prospective teachers about tolerance education. Educational Research and Reviews, 6(1), 77-86.

Tatar, A. F. (2009). Okul öncesi ĕ̌itiminde (5-6 yaş) hoşgörü ĕgitimi. Yayımlanmamış Yüksek Lisans Tezi, Ankara Üniversitesi, Sosyal Bilimler Enstitüsü, Ankara. http://tez2.yok.gov.tr/ adresinden edinilmiştir. 
Anadolu Journal of Educational Sciences International, January 2015, 5(1)

Tezcan, M. (1995). Türk kültüründe hoşgörü. Uluslararası Hoşgörü Kongresi, Antalya.

Thompson, W. C. (2010). Reconsidering tolerance education: should we recover tolerance or replace it with hospitality? Philosophy of Education, 346-348.

Topuz, H. (1996). Siyasal yaşamda hoşgörü. B. Onur (Ed.). Hoşgörü ve eğitim içinde (ss. 137146). Ankara: Türk Eğitim Derneği Yayınları.

Türe, H. ve Ersoy, A. F. (2014). Sosyal bilgiler öğretmenlerinin hoşgörü algısı. Journal of Social Studies Education Research, 5(2), 31-55.

UNESCO (1995). The declaration of principles on tolerance. http://unesdoc.unesco.org/images/0015/001518/151830eo.pdf 20.11.2012 tarihinde alınmıştır.

UNESCO (1994). Tolerance: The threshold of peace. http://unesdoc.unesco.org/images/0009/000981/098178e.pdf2 05.01.2012 tarihinde alınmıştır.

Weidenfeld, W. (2002). Constructive conflicts: tolerance learning as the basis for democracy. Prospects, 32(1), 95-102.

Welton, D., \& Mallan, J. T. (1999). Children and their world: strategies for teaching social studies. New York: Houghton Mifflin Company.

Widmalm, S. (2005). Trust and tolerance in India: findings from Madhya Pradesh and Kerala. India Review, 4, 233-257.

Yıldırım, A., ve Şimşek, H. (2011). Sosyal bilimlerde nitel araştırma yöntemleri. Ankara: Seçkin Yayinc1lik.

Yılmaz, M. S. (2005). Türkiye Cumhuriyeti inkılap tarihi ve Atatürkçülük dersi konularının ilköğretimde öğretimi. Y. Doğaner (Ed.) Türk eğitim sisteminde Atatürkçülük ve 
Anadolu Journal of Educational Sciences International, January 2015, 5(1)

Cumhuriyet Tarihi Öğretimi içinde (ss.23-44). Ankara: Hacettepe Üniversitesi Yayınları, 2006.

Yürüsşen, M. (1996). Liberal bir değer olarak ahlaki ve siyasi hoşgörü. İstanbul: Yapı Kredi Yayınları. 